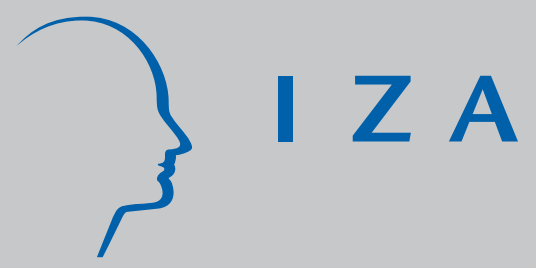

IZA DP No. 871

The Impact of Growth, Labour Cost and Working Time on Employment: Lessons from the French Experience

Yannick L'Horty

Christophe Rault

September 2003 


\title{
The Impact of Growth, Labour Cost and Working Time on Employment: Lessons from the French Experience
}

\author{
Yannick L'Horty \\ EPEE, University of Evry Val d'Essonne \\ Christophe Rault \\ EPEE, University of Evry Val d'Essonne, \\ EUREQua, Sorbonne University and IZA Bonn
}

\section{Discussion Paper No. 871 \\ September 2003}

\author{
IZA \\ P.O. Box 7240 \\ D-53072 Bonn \\ Germany \\ Tel.: +49-228-3894-0 \\ Fax: +49-228-3894-210 \\ Email: iza@iza.org
}

This Discussion Paper is issued within the framework of IZA's research area The Future of Labor. Any opinions expressed here are those of the author(s) and not those of the institute. Research disseminated by IZA may include views on policy, but the institute itself takes no institutional policy positions.

The Institute for the Study of Labor (IZA) in Bonn is a local and virtual international research center and a place of communication between science, politics and business. IZA is an independent, nonprofit limited liability company (Gesellschaft mit beschränkter Haftung) supported by Deutsche Post World Net. The center is associated with the University of Bonn and offers a stimulating research environment through its research networks, research support, and visitors and doctoral programs. IZA engages in (i) original and internationally competitive research in all fields of labor economics, (ii) development of policy concepts, and (iii) dissemination of research results and concepts to the interested public. The current research program deals with (1) mobility and flexibility of labor, (2) internationalization of labor markets, (3) welfare state and labor market, (4) labor markets in transition countries, (5) the future of labor, (6) evaluation of labor market policies and projects and (7) general labor economics.

IZA Discussion Papers often represent preliminary work and are circulated to encourage discussion. Citation of such a paper should account for its provisional character. A revised version may be available on the IZA website (www.iza.org) or directly from the author. 
IZA Discussion Paper No. 871

September 2003

\section{ABSTRACT}

\section{The Impact of Growth, Labour Cost and Working Time on Employment: Lessons from the French Experience*}

To account for employment evolutions at the macro-economic level, we propose a modelling where employment is explained by added value, working time and real labour cost. Estimations using quarterly French macro-economic data are carried out in a multivariate framework for three sets of sectors. We get a relationship in which employment rises with growth and decreases when labour cost or working time rises in industrial sectors as well as in non-industrial ones. This model then permits to measure retrospectively the contributions of each of the variables to employment inflections since the mid-eighties.

JEL Classification: E24, J22, J23

Keywords: Per capita productivity, hourly productivity, labour demand, employment, working time, cointegration, VAR-ECM model

Corresponding author:

Christophe Rault

Department of Economics

University of Évry Val d'Essonne

4 Boulevard François Mitterrand

91025 Évry-Cedex

France

Email: chrault@hotmail.com

\footnotetext{
* Financial support from the French Labour Ministry through the research program «Emplois flexibles, salaries rigides $»$ is gratefully acknowledged.
} 


\section{INTRODUCTION}

Since the early eighties productivity gains have known a new decrease in France and growth content has risen in employment. For the same rate of growth it seems as if French economy has become able to generate more jobs. Evidences show that between 300 and 500,000 jobs, essentially located in the service sector have been preserved in spite of the slowing down of activity since the 1993 recession.

The aim of this study is to try to explain these evolutions. We propose a modelling of French employment and confront it with quarterly macro-economic data using multivariate econometric techniques. We consider employment determinants by providing a general and theoretical specification. The estimations are based on definitive series of quarterly accounts covering the 1976.1 to 1996.4 period and concern non agricultural manufacturing sectors, as well as industrial and non-industrial ones (composed mainly of the service sector) ${ }^{1}$.

In section 2 we present a productivity modelling and econometric estimations using Johansen's methodology $(1988,1995)$. In this specification employment depends on three main determinants: added value, working hour and real labour cost. A higher growth, a working hour or labour cost reduction have a positive impact on employment and permits a satisfactory reproduction of the French unemployment evolution over the past twenty years. A final section reviews our main findings.

\section{Modelling productivity and employment}

Macro econometric estimations of the link between growth and employment distinguish between the short-run dimension reflecting the productivity cycle, and the long-run dimension related to the trend productivity gains. To obtain the long run target, one can regress a productivity indicator on a temporal polynomial, generally a linear or quadratic trend. The trend productivity target constitutes the error correcting term mechanism of an error correction model.

\footnotetext{
${ }^{1}$ At the end of 1996 industrial manufacturing sectors amount to 4.2 million salaried employees and non industrial non agricultural sectors to 9.1 million, including 8 million in the service sectors and 1.1 million in the building trade.
} 
From a theoretical point of view, this modelling rests upon rather restrictive assumptions. It supposes that employment is connected in a stable way to growth, independently of any other determinants. It is thus implicitly assumed that labour cost, capital cost, or working time have no long-term influence on employment or productivity at a macro-economic level.

From a theoretical point of view, it seems preferable to retain a less restrictive form of the employment equation where the elasticities of its different determinants, output, labour cost, and working time are not a priori constrained. It is such estimations that Laffargue and L'Horty (1997) carried out in a univariate framework. The explanation gains in generality without prejudging its consequences on employment. This lack of restriction is also in accordance with what data indicate. Whether it is specified in manpower or in hours worked, labour productivity is actually a non-stationary variable in the usual field of observation. Thus productivity conventional modelling leads systematically to nonstationary residuals at the $5 \%$ level. As it is shown by the estimations and the tests in appendix 2, this report is verified whether productivity is specified in manpower or in hours worked, whether we consider non agricultural manufacturing sectors, or only industrial or non- industrial ones and finally whether labour cost is included or not in the estimation ${ }^{2}$.

For these theoretical and empirical reasons, our approach is to wonder whether adopting more general specifications compatible with non constant return scales and/or an imperfect substituability of men to hours worked can lead to a more satisfactory empirical modelling. Before testing this, it is necessary to have first a theoretical framework leading to a general employment equation which corresponds to an estimable long-run relationship. This is necessary if we want to give a structural interpretation of the parameters which determine employment.

\footnotetext{
${ }^{2}$ On the contrary Maurel (1990) found that only hourly productivity was non stationary using quarterly data covering the 1970-1989 period
} 


\subsection{The theoretical determinants of employment}

The model presented in this sub-section is both simple and general. It is simple because we only distinguish two production factors, labour and capital, expressed in effective units, we consider a representative firm which minimises its production costs and we only deal with the conditional elasticities of employment to these three determinants. The log-linear expression of our employment equation can be written as $n=a y+b w+c h$, where $n$ represents occupied manpower, y production level, w real labour cost, and h the length of working time (hereafter working time), all these variables being expressed in natural logarithms. The coefficient of each variable denotes the conditional elasticities of employment to the corresponding variables. It is obvious that a labour cost increase modifies the employment level both for a given production through the substitution possibilities between factors, and also via the modification of the production level related to the price variation which accompanies the modification of production costs ("volume" effect). Unconditional elasticities take all these effects into account whereas conditional elasticities only correspond to the effects for a given production, i.e. without the "volume" effect. Here, we focus exclusively on conditional elasticities because they can be deduced directly from our econometric estimations. Anyway, the difference at the aggregated level is likely to be low since market power is higher at a macroeconomic level and since volume effect decreases with it.

The model nevertheless will be very general in so far as production function will not be specified and will only be assumed to be homogeneous of degrees $\theta$, nor the nature of the scale returns, market structures, the capital-labour substituability degree or the men to the substituability degree of hours worked.

The conditional labour demand which minimises the production costs for a given output level verifies the Shephard Lemma: $\overline{\mathrm{L}}=\mathrm{C}_{\mathrm{W}}(\mathrm{W}, \mathrm{R}, \mathrm{Y})$, where $C_{W}$ is the derivative of the cost function with regard to labour cost. By differentiating this equation and by introducing the elasticities of employment to labour cost, to capital and to output level, we obtain an expression of the conditional labour demand where the employment growth of rate only depends on the relative labour cost growth of rate and on the production one. The conditional elasticity of employment to labour cost can then be expressed with respect to the 
substitution elasticity between capital and labour $\sigma=\frac{\mathrm{CC}_{\mathrm{WR}}}{\mathrm{C}_{{ }_{W} C_{R}}}$ and with respect to the wage share in the added value (denoted s). As for the production elasticity to employment, it is equal to the homogeneity degree of the cost function which is the opposite of that of the production function, $\theta$.

$$
\frac{\mathrm{dL}}{\mathrm{L}}=-\sigma(1-\mathrm{s})\left(\frac{\mathrm{dW}}{\mathrm{W}}-\frac{\mathrm{dR}}{\mathrm{R}}\right)+\frac{1}{\theta} \frac{\mathrm{dY}}{\mathrm{Y}}
$$

The conditional labour demand decreases when the relative labour cost goes up, all the more as the substitution possibilities are high, and when production decreases. This expression is very general and is in particular independent of the technology used, i.e. of the nature of the production function, or of the functions which can be deduced from it (cost or profit function).

Employment measured in effective units (L) corresponds to the product of manpower $(\mathrm{N})$ by an effort function, $\mathrm{e}(\mathrm{h})$ which depends on working time. It differs from employment in hours worked $(\mathrm{H})$, which is by definition equal to the product of employment expressed in manpower $(\mathrm{N})$ by working time (h). Working time is then likely to affect the employment level through three relays: its impact on hourly labour productivity, its impact on equipment use length and the wage compensation degree related to working time variations. The effort elasticity to working time is denoted $\eta_{h}^{e}$, the elasticity of the length of equipment use to working time is denoted $\eta_{h}^{d}$, the impact of a length of working time variation on the hourly wage depends on the wage compensation degree, denoted $\gamma$ (the wage compensation is equal to zero when $\gamma=0$, it is complete when $\gamma=1$ ). It can be shown that at the producer optimum, the labour cost elasticity to working time depends on the three above parameters related to working time introduction.

$$
\eta_{\mathrm{h}}^{\mathrm{W}}=1-\gamma-\eta_{\mathrm{h}}^{\mathrm{e}}+\eta_{\mathrm{h}}^{\mathrm{d}}
$$

The complete expression of the labour demand equation is then given by:

$$
\frac{\mathrm{dN}}{\mathrm{N}}=-\sigma(1-\mathrm{s})\left(\frac{\mathrm{dW}}{\mathrm{W}}-\frac{\mathrm{dR}}{\mathrm{R}}\right)+\frac{1}{\theta} \frac{\mathrm{dY}}{\mathrm{Y}}-\left[\sigma(1-\mathrm{s})\left(1-\gamma-\eta_{\mathrm{h}}^{\mathrm{e}}+\eta_{\mathrm{h}}^{\mathrm{d}}\right)+\eta_{\mathrm{h}}^{\mathrm{e}}\right] \frac{\mathrm{dh}}{\mathrm{h}}
$$


Finally, we obtain by integration a log linear expression of employment in level whose elasticities have a clear theoretical meaning. This expression will be used to interpret our estimation results.

$$
\mathrm{n}=-\sigma(1-\mathrm{s})(\mathrm{w}-\mathrm{r})+\frac{1}{\theta} \mathrm{y}-\left[\sigma(1-\mathrm{s})\left(1-\gamma-\eta_{\mathrm{h}}^{\mathrm{e}}+\eta_{\mathrm{h}}^{\mathrm{d}}\right)+\eta_{\mathrm{h}}^{\mathrm{e}}\right] \mathrm{h}+\text { cste }
$$

Occupied manpower decreases when relative labour cost goes up all the more as substitution possibilities are high, and rise with activity (when scale returns are constant this employment equation becomes a productivity equation). The impact of working time is less straightforward to comment. A working time decrease leads to a reduction of hours worked if it increases labour cost $\left(\eta_{\mathrm{h}}^{\mathrm{W}}\right.$ negative) and it will be the case if it is compensated for by an increase of hourly wages ( $\gamma$ close to one), if it comes along with reorganisations in the production process ( $\eta_{\mathrm{h}}^{\mathrm{d}}$ close to zero) and if it has a limited impact on hourly productivity ( $\eta_{\mathrm{h}}^{\mathrm{e}}$ close to one). Then, the working time reduction will have a negative impact on employment when it is measured in effective units or in hours worked, but it will be nevertheless always favourable to employment measured in occupied manpower (if and only if $\left.\eta_{h}^{\mathrm{e}}>\eta_{\mathrm{h}}^{\mathrm{L}}\right)$.

The effort elasticity to working time, $\eta_{\mathrm{h}}^{\mathrm{e}}$, which measures the substituability degree of men to hours, or the impact of a length of working time reduction on the hourly productivity, is therefore a crucial parameter. Two opposite effects are at work When the effort elasticity to working time is high, a working time reduction has a limited upward impact on hourly productivity, or even decreases hourly productivity if this elasticity is higher than unity (the «warm-up effect» is in this case stronger than the "tiredness effect»). This hourly productivity decrease is favourable to employment in a strict logic of men to hour worked substitution, but it is unfavourable to employment because it renders hourly labour cost more expensive and decreases hours worked. This negative effect depends on the substitution possibilities between factors, which is not the case for the former. All in all, if substitution possibilities are not too important, $\left(\sigma<\frac{1}{1-\mathrm{s}}\right)$, the positive effect is higher than the negative one: a high effort elasticity to working time thus strengthens the positive effects of a length of working time reduction on occupied manpower. 


\subsection{Unrestricted multivariate econometric estimations of employment equations}

The use of multivariate estimations enables to describe the interdependences between employment, added value, working time and labour cost without making any a priori assumption on the value of the elasticities linking those variables and to test the existence of long run relationships. This sub-section proposes a non-constrained error-correction (VARECM) modelling for these four variables and for each sector under study ${ }^{3}$, the estimation sample covers the 1970-1 to 1996-4 period.

A specific problem is related to the measure of capital cost. In the empirical studies surveyed by Hamermesh (1993), the effort made by the empirical researcher to measure other factor prices than that of labour, particularly that of capital is not much rewarded by a noticeable modification of the obtained results. On macroeconomic data, Dormont (1997) estimated a model where labour and capital cost were separated but found that capital cost was systematically non significant. These results incite us to retain a specification where capital cost is not included in the relative factor costs and where only labour cost is considered.

The econometric methodology implemented here (cf. appendix 3 for further details) provides the following estimations of the long-run relationship among our four variables, for each of the three sectors under consideration:

$\mathrm{n}_{\mathrm{t}}=0,786 \mathrm{y}_{\mathrm{t}}-0,083 \mathrm{~h}_{\mathrm{t}}-0,083(\mathrm{w}-\mathrm{p})_{\mathrm{t}}-0,003$ trend

(Non agricultural manufacturing sectors NAMS)

$\mathrm{n}_{\mathrm{t}}=1,172 \mathrm{y}_{\mathrm{t}}-0,762 \mathrm{~h}_{\mathrm{t}}-0,304(\mathrm{w}-\mathrm{p})_{\mathrm{t}}-0,006$ trend

(Industrial sectors, IS)

$\mathrm{n}_{\mathrm{t}}=0,555 \mathrm{y}_{\mathrm{t}}-0,254 \mathrm{~h}_{\mathrm{t}}-0,212(\mathrm{w}-\mathrm{p})_{\mathrm{t}}+4,068$

(Non industrial sectors, NIS)

\footnotetext{
${ }^{3}$ It is important to have in mind that the tested structural model is of course the same for each of the three sectors and is given by equation (1). However empirically, we have to specify and to estimate three distinct error-correction specifications, one for each sector, which leads us to speak at some moments of three VARECM models.
} 
In these three estimations the set of coefficients has a sign in accordance with the predictions of the theoretical model. Real labour cost (w-p) and working time appear with a negative sign. In the long term and when the independences between variables are taken into account, the reduction of real labour cost and the reduction of working time thus go hand in hand with an employment increase in non agricultural manufacturing sectors as well as in industrial and non-industrial ones. The differences between these two sets of sectors are however strong.

A structural interpretation of these results can be obtained from the theoretical model. The identification of the various parameters which results from it is given in table 1. First of all, the scale returns (parameter $\theta$ ) would be slightly increasing in the non agricultural manufacturing sectors, slightly decreasing in the industrial ones and increasing in the non industrial ones, where productivity is lower and growth content richer in employment. Then, capital and labour would be little substituable for the set of sectors, and hence employment would be little sensitive to its cost at the aggregated level. We find again a traditional result of French macro-econometric models, carefully commented by Dormont (1997). However, as she suggested, the possibilities of substitution would be more important at a desaggregated level. The elasticities of substitutions are indeed higher in the non industrial sectors and still higher in the industrial ones where the possibilities of substitution are close to those of a Cobb-Douglas production function ${ }^{4}$. The elasticity of employment to labour cost would be close to 0.2 in the non-industrial sectors and to 0.3 in industrial ones, which corresponds to the central value given by Hamermesh (1993) in his survey of applied studies carried out in other countries than France.

\footnotetext{
${ }^{4}$ Higher substitution possibilities at the desagregated level than at the aggregated one suggest some phenomena of draining of employment between sectors when labour cost modifications happen, phenomena which are not captured by the aggregated elasticities. These phenomena also explain distances between aggregated and disintegrated levels for the other parameters.
} 
Table 1 - Interpretation and identification of structural parameters

\begin{tabular}{lcccc}
\hline & $\begin{array}{c}\text { Scale returns } \\
(\theta)\end{array}$ & $\begin{array}{c}\text { capital to } \\
\text { labour } \\
\text { substitution } \\
\text { elasticity }(\sigma)\end{array}$ & $\begin{array}{c}\text { Elasticity of } \\
\text { employment to } \\
\text { its cost }\left(\bar{\eta}_{\mathrm{W}}^{\mathrm{L}}\right)\end{array}$ & $\begin{array}{c}\text { Elasticity of } \\
\text { manpower to } \\
\text { working time } \\
\left(\eta_{\mathrm{h}}^{\mathrm{N}}\right)\end{array}$ \\
\hline NAMS & 1,27 & 0,28 & -0.08 & $-0,17$ \\
IS & 0,85 & 1,01 & -0.3 & $-1,07$ \\
NIS & 1,8 & 0,7 & -0.21 & $-0,47$ \\
\hline
\end{tabular}

Note: for all sectors, the share of wages in the added value is supposed to be equal to $70 \%$. $(=0,7)$. In the estimations of the three cointegrating relationships labour cost is a per capita one and not an hourly one, which modifies the elasticity of manpower to working time.

The effect of a working time reduction on occupied manpower is always positive but this is clearer at the desaggregrated level than at the aggregated one. In non industrial sectors a length of working time reduction of $10 \%$ induces a rise of occupied manpower close to $5 \%$ (and hence a decrease of hours worked by $5 \%$ ). We obtain a little less than "the rule of three" in these sectors. The impact is the most significant in industrial sectors where a working time reduction has no effect on the hours worked, or slightly increases them, and increases strongly occupied manpower (we are then close to "the rule of three") ${ }^{5}$.

This result for industrial sectors is all the more remarkable as employment seems to be more sensitive to labour cost than in non industrial ones, which is not a favourable condition for employment. To interpret this more significant effect of working time in industrial sectors, it is important to decompose what is connected to the effort elasticity to working time on the one hand, and what comes from the other parameters, on the other. Our estimation strategy does not allow us to identify each of the theoretical parameters but we can always calculate the value of one of them conditionally on the value assumed for the others. We proceed like this in table 2 where we consider two extreme assumptions for the wage compensation degree and the equipments use length elasticity to labour, in order to deduce the value of the effort elasticity to working time

\footnotetext{
${ }^{5}$ Let us recall that we only measure here the long-run effects of working time reduction as it has occurred in France from the beginning of 1976 to the end of 1996: this is not a forward-looking report which would be valid for a collective length of working time reduction as the one implemented in France since the 1998 law on the passage to a 35- hour workweek whose modalities are historically original.
} 
Table 2 - Conditional identification of the effort elasticity to the length of working time $\left(\eta_{h}^{\mathrm{e}}\right)$

\begin{tabular}{lccc}
\hline & $\begin{array}{c}\text { Minimal value } \\
\left(\eta_{\mathrm{h}}^{\mathrm{d}}-\gamma=1\right)\end{array}$ & $\begin{array}{c}\text { Central value } \\
\left(\eta_{\mathrm{h}}^{\mathrm{d}}-\gamma=0\right)\end{array}$ & $\begin{array}{c}\text { Maximal value } \\
\left(\eta_{\mathrm{h}}^{\mathrm{d}}-\gamma=-1\right)\end{array}$ \\
\hline NAMS & 0 & 0,09 & 0,18 \\
IS & 0,66 & 1,09 & 1,53 \\
NIS & 0,054 & 0,32 & 0,59 \\
\hline
\end{tabular}

It appears that it is not possible to interpret theoretically the differences of behaviours between the sets of sectors without making differences in the effort elasticity to working time which play an important role. Differences between sectors concerning the wage compensation degree and the reorganization dimension would thus play a secondary role in the explanation of the effects of working time on employment. The effort elasticity to working time would be the lowest at the aggregated level, where a working time reduction would entail a high labour hourly productivity increase. It would have an intermediate value in non industrial sectors and would be the higher in industrial ones. In these sectors, men and hours worked are more substitutable than some elsewhere. A working time reduction is even likely to have no effect on hourly productivity and it decreases consequently labour measured in effective unity. If industrial sectors are those where working time reduction produces the most favourable effects on occupied manpower, it is because it raises less than in other sectors the labour hourly productivity which is favourable to employment by a sharing effect.

\section{A retrospective explanation}

We thus obtain a better representation of the employment determinants when we take growth, working time and labour cost at the same time into account. It is theoretically less restrictive than the conventional approach and in accordance with the statistical properties of data. What are the teachings of this representation? 


\subsection{No break in the nineties}

First of all, the model does not exhibit any significant break in the nineties. The Chow tests which measure the parameter stability through time confirm it (cf. appendix 2). Graph 1 illustrates this model stability and represents the dynamic simulation results from 1985 carried out with the model re-estimated over the 1976-1 to 1992-4 period. In the studies on the enrichment growth content in employment this type of simulation exhibits an important downturn in employment beyond the estimation period and it is this downturn which has been at the origin of the subject of the enrichment growth content in employment. Here things are different since the simulated series remain very close to the observed ones in the three sets of sectors (including services). In particular no permanent excess of the simulated employment appears with respect to effective employment. The fact of having begun dynamic simulations in 1985 should all the same favour such downturns.

In manufacturing sectors, effective employment is moreover lower than simulated employment contrary to what the notion of employment growth enrichment suggests. The gap reaches 160,000 jobs in 1993 but it is quickly reduced before increasing again at the end of the period when it reaches 62,000 jobs. In industrial sectors effective employment is also lower than simulated employment with a gradually increasing gap reaching over 100,000 jobs at the end of 1996. It is only in industrial sectors where the evolution is in accordance with the theme of the enrichment growth content in employment: the gain is about 115,000 jobs in 1995 and it is lower after (it is 62,000 jobs at the end of the period). Here, we find again a result obtained by other studies which stressed the very sectorial aspect on services of the enrichment growth content in employment (Lerais, 2001), even if the gaps here remain modest. 
Graph 1. Simulation of employment

1-a. Manufacturing sectors

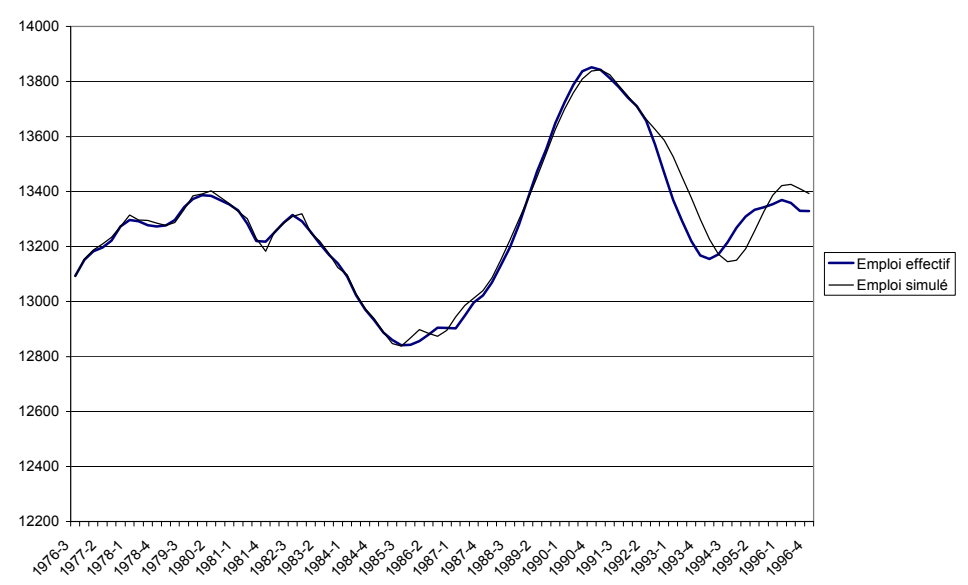

1-b. Industrial sectors

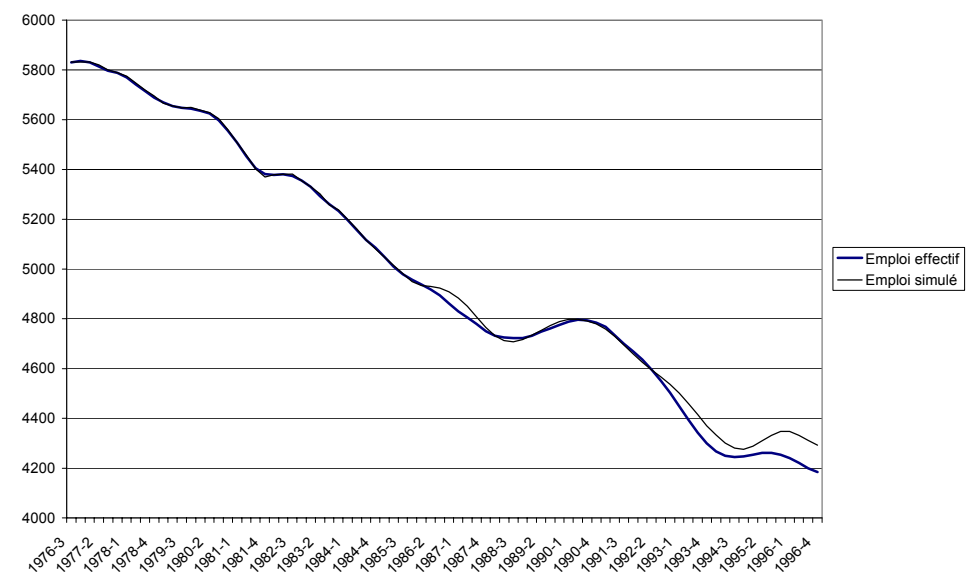

1-c. Non-industrial sectors

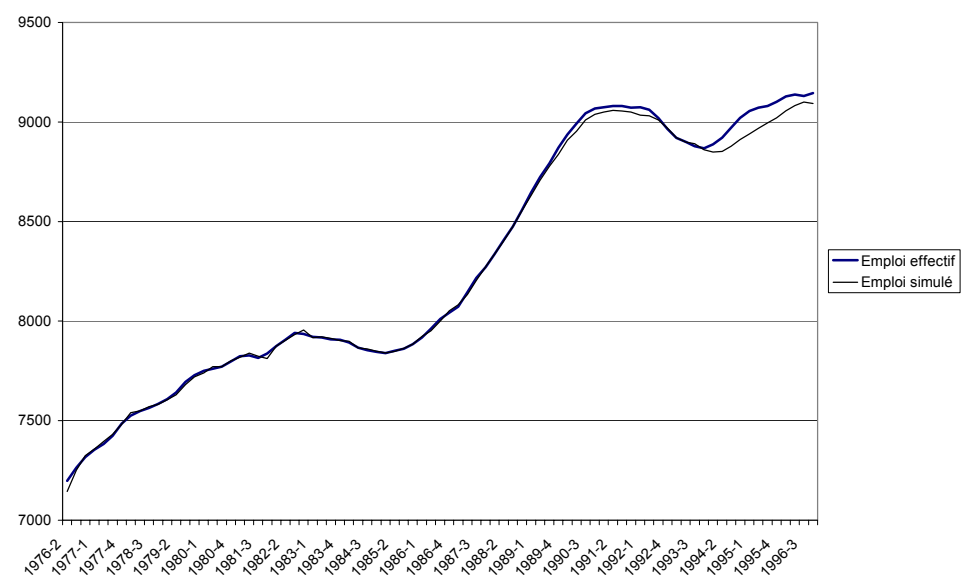




\subsection{The retrospective contributions of growth, working time and labour cost}

If there are no breaks of employment behaviour, we can use our model to estimate the retrospective contribution of working time, or of labour cost. To this end, we used all the data set (estimation period: 76-1 , 96-4) to estimate for each sector a complete model, with a long-run target as well as the short-run dynamics in which the non significant terms have been deleted. A first dynamic simulation was realized from 1985 with the actual values of growth, working time and labour cost. To estimate the working time contribution, we implemented a second dynamic simulation supposing that working time remained fixed to its value of the first quarter of 1981 . To estimate the labour cost contribution, we carried out a third simulation supposing that real cost progressed after 1985 at the same rhythm as previously. Over the 1975 to 1985 decade this progress was respectively of $2.5 \%, 2.7 \%$ and $2.4 \%$ every year for manufacturing sectors, industrial ones, and non industrial ones, whereas it was of $1 \%, 1.2 \%$ and $1.05 \%$ afterwards. Then, the simulated employment corresponds to the one that we would have obtained in the absence of such a labour cost moderation. The results of these three simulations for three sectors are reported on graph 2. These simulations show a positive contribution of the working time reduction and of the labour cost moderation in the three sets of sectors. The models being estimated separately, the sum of the contributions for the industrial and non industrial sectors has no reason to be identical to that calculated for the set of sectors. Actually, the impact obtained for manufacturing sectors is higher than the cumulated impacts for industrial and non industrial ones. The differences of behaviour put in evidence between sectors in section 2 lead us not to retain the aggregated estimation and to focus on the desaggregated estimations. Therefore in what follows, we will concentrate our comments on the desaggregated results. 
Graph 2. Retrospective contributions

2-a. Manufacturing sectors

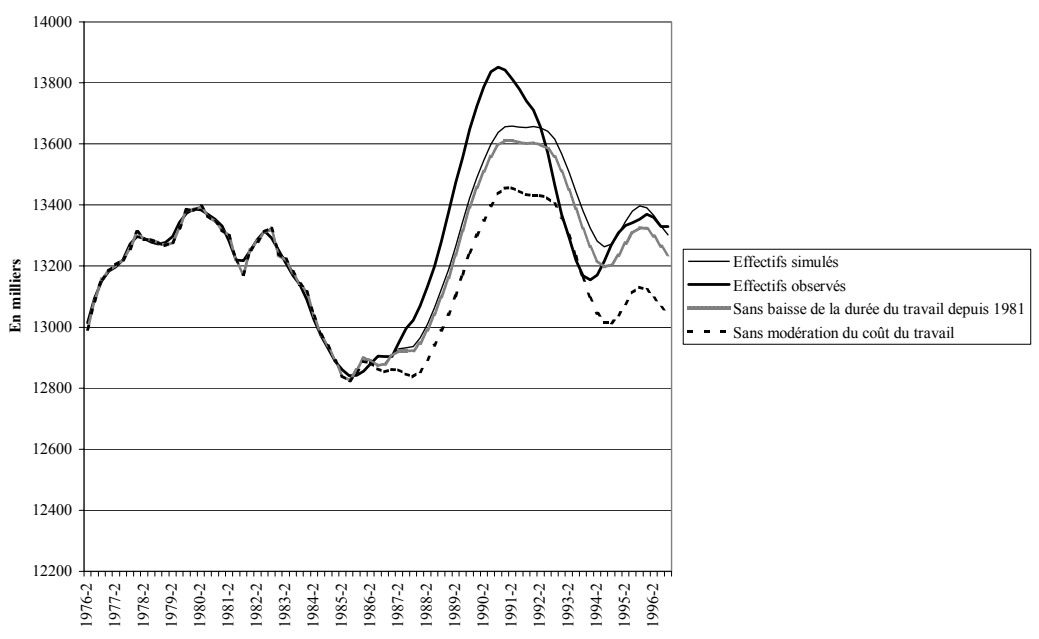

2-b. Industrial sectors

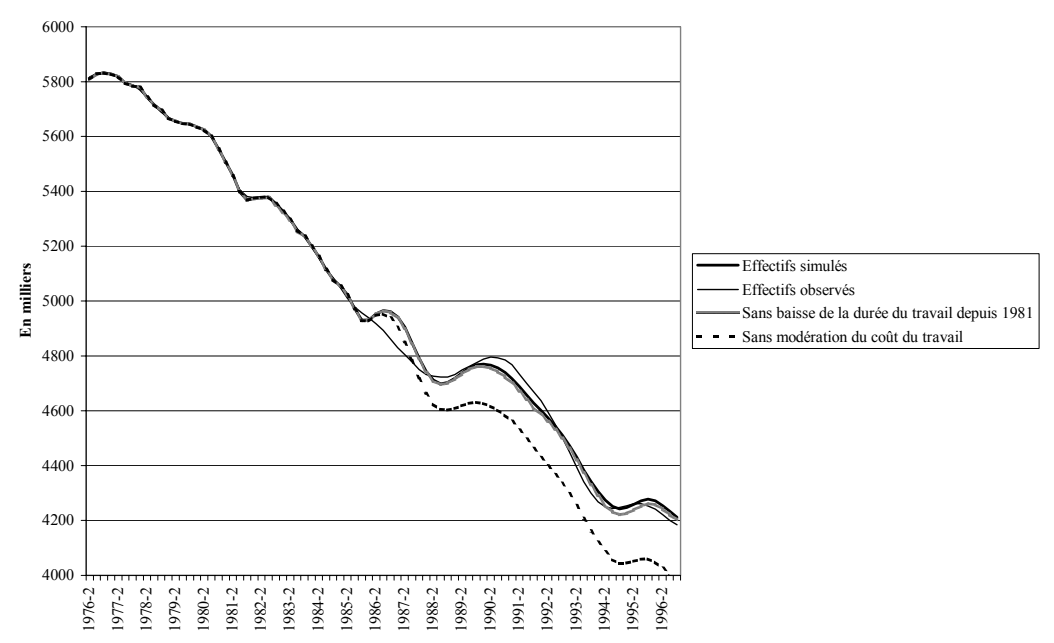

2-c. Non-industrial sectors

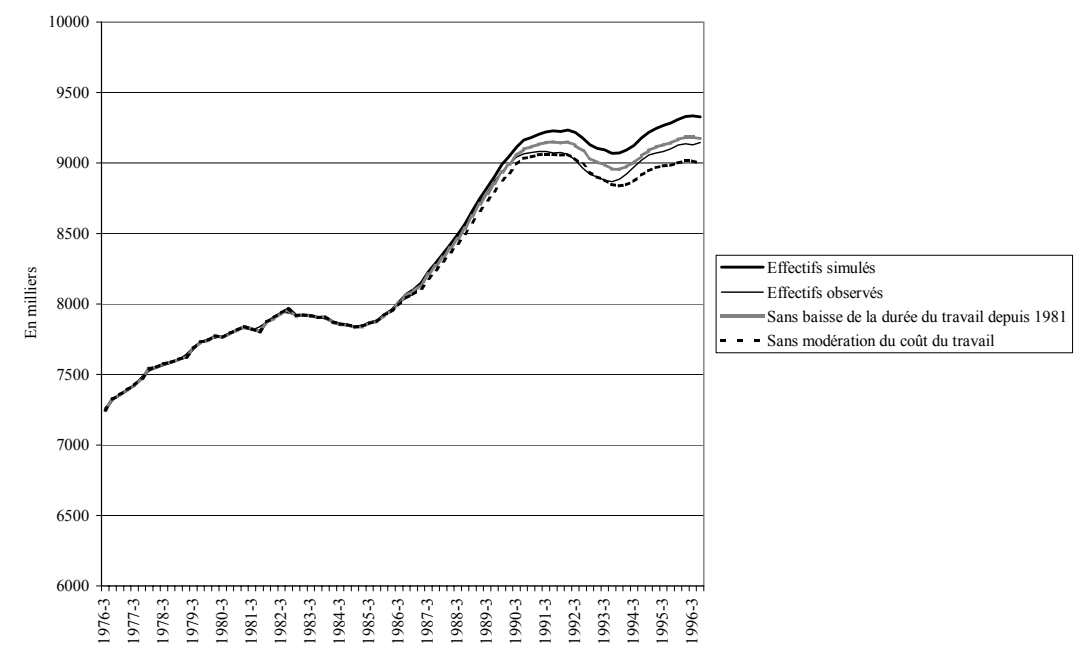


The impact of labour cost moderation from the mid-eighties is the most sensitive in all simulations. This moderation would have led to the creation of 240,000 jobs in industrial sectors and 330,000 in non industrial ones, corresponding to the respective increases of 5.6 $\%$ and $3.6 \%$ of employment in the two sets of sectors. These findings are in accordance with the elasticities reported in section 2 given the labour cost moderation dimension in the two sets of sectors. They indicate a higher sensibility of employment to labour cost in industrial sectors (which are also the most exposed to international competition).

Besides, these job creations are more massive at the end of the period: on the 330,000 jobs gained in non industrial sectors since 1985, 125,000 were gained between the second quarter of 1993 and the end of 1996, after the implementation of social contribution lowerings in France. It is the case for 60,000 jobs out of 240,000 in industrial sectors. Even though the carried out method does not allow us to attribute exactly this increase of job creations to social contribution lowerings, our results suggest an important impact of these measures.

With the working time reduction 155,000 jobs have been gained in non-industrial sectors. Nearly half of these jobs were gained after 1992, i.e. after the part-time job development expansion which followed the implementation of national insurance contribution deductions. In industrial sectors, we count an excess of 10,000 jobs. These figures represent respectively $1.7 \%$ and $0.2 \%$ of the simulated employment in the two sets of sectors. The working time effect thus seems globally more modest than that of labour cost. Let us underline however that if working time was supposed unchanged at its level of the beginning of 1981 where it was still legally of 40 hours, simulations only began after 1985 . Consequently, we have only measured the effects of working time reduction since 1985,a period during which it was very low in the two sets of sectors.

Activity growth accounts for the set of the other employment inflections. From the beginning of 1985 to the end of 1996, growth would thus explain $1,005,000$ jobs created in non industrial sectors and 1,090,000 jobs destroyed in industrial ones. For the set of non agricultural manufacturing sectors, the net effect is a loss of 85,000 jobs. 


\section{CONCLUSions}

The aim of this study has been to ponder over employment macroeconomic determinants through the French experience since the mid-seventies using multivariate estimations of employment equations on quarterly macroeconomic data. These estimations have been implemented on non agricultural manufacturing sectors and for a partition of them into industrial sectors on the one side and non industrial ones on the other, in order to allow for the possibility of a specific sectorial behaviour. The main conclusions which emerge from this research are the followings.

Employment does not only depend on growth rhythm. The difference between growth and employment progression, per capita productivity gains is not stationarity through time. It's the same for hourly productivity. The conventional models which suppose a regular progression of productivity in time are thus not compatible with the statistical properties of data. They are also theoretically restrictive. The observation of an employment growth enrichment which would have appeared in France since 1992-1993, obtained with such modelling can therefore be questioned.

Employment also depends on working time and labour cost in industrial sectors as well as in non-industrial ones. The working time reduction increases hourly labour productivity, men and hours being imperfect substitutes. Taking working time into account in employment determinants is a necessary and sufficient condition to get a stationary relation

When the set of interdependences between employment, activity, working time and labour cost are taken into account in a multivariate framework, we obtain a relation where employment rises with growth and decreases when labour cost or working time rises, both in industrial and non-industrial sectors. This relation is effectively an employment equation since the three other variables are weakly exogenous. It doesn't show any particular instability in the eighties whatever the considered sectorial cut is. Therefore there is not any particular excess of job creations over this period with respect to this growth evolution when both the inflexions of working time and those of labour costs are taken into account. More precisely, the actual manpower in manufacturing sectors is lower than simulated employment contrary to what the notion of enrichment growth content suggests in 
employment. It is also the case in industrial sectors. It is only in non industrial ones in which the evolution is in accordance with the theme of the enrichment growth content in employment hence confirming the very sectorial aspect of this enrichment.

Dynamic simulations allow us to determine the respective contributions of these three factors. In industrial sectors, these simulations explain how the 840,000 jobs lost from the beginning of 1985 to the end of 1996 are divided. This activity weakness would have led to the loss of 1,090,000 jobs, but it was partially compensated for by a labour cost moderation $(+240,000$ jobs $)$ and in a more marginal way by the weak decrease of working time reduction $(+10,000$ jobs). In non industrial sectors where simulations have led to $1,490,000$ created jobs since 1985, growth is responsible for 1,005,000 jobs, labour cost moderation for 330,000 and working time reduction for 155,000 .

\section{References}

ENGLE R.F, GRANGER C.W.J (1987), « Cointegration and error correction : representation and testing », Econometrica, Vol 55, PP 251-276.

FULLER W.A.(1976), « Estimation and hypothesis testing for non stationary time series », Ph. D. Thesis, Iowa State University, Ames.

HAMERMESH D.S.(1993), Labor demand, Princeton University Press.

HART R.A. (1987), Working time and Unemployment, Allen and Urwin, London.

JOBERT T. (1992), "Test de racine unitaire : une stratégie et sa mise en oeuvre », Cahiers Ecomath, Université de Paris I, n 92,44 .

JOHANSEN S. (1995) : «Likelihood-based inference in co-integrated vector autoregressive models », Oxford University Press, 267 P.

JOHANSEN S. (1988), "Statistical Analysis of cointegration vectors », Journal of Economic Dynamics and Control, ${ }^{\circ} 12$, pp.231-254.

KWIATKOWSKI D., PHILLIPS P.C.B, SHIN Y.(1992), " Testing for the null hypothesis of stationarity against the alternative of a unit root », Journal of Econometrics, Vol 54, pp 159-178.

LAFFARGUE J-P, L'HORTY Y. (1997), « Emploi d'équilibre et formation des salaires : une étude sectorielle », Economie et Prévision, n²127, pp 117-135. 
MAUREL F. (1990), «Dynamique de l'emploi et tendance de la productivité dans les années $1980 »$, Economie et Statistique, n²37-238, pp151-162.

OSTERWALD- LENUM M. (1992), « A note with quantiles of the asymptotic distribution of the maximum likelihood cointegration rank test statistics », Oxford Bulletin of Economics and Statistics, vol 54, n 3, pp 461-472.

PESARAN, M.H, SHIN Y., SMITH J.S (1999), « Structural analysis of vector error correction models with exogenous I1) variables », Manuscript, University of Cambridge, http: // www.econ.cam.ac.uk/faculty/pesaran/

PRADEL J., RAULT C, (2003), « Exogeneity in VAR-ECM models with purely exogenous longrun paths», forthcoming in Oxford Bulletin of Economics and Statistics.

RAULT C. (2000), « Non-causality in VAR-ECM models with purely exogenous long run paths », Economics Letters, $\mathrm{n}^{\circ} 67-2$.

SCHMIDT P., PHILLIPS P.C.B (1992), « LM tests for a unit root in the presence of determinist trends », Oxford Bulletin of Economics and Statistics, Vol 54, n³, pp 257-287.

WHITE H. (1980), « A heteroskedastic- consistent covariance matrix estimator and a direct test for heteroskedasticity », Econometrica, vol 48, pp 817-838.

\section{Appendix 1}

\section{Database}

The notation is the following: higher-case letters denote variables in level and lower-case letters indicate the natural logarithm of the corresponding variable, $\mathrm{q}:$ added value, $1:$ salaried employment (in manpower) $\mathrm{h}$ : the working time; (w-p) : real labour cost.

All series used for non agricultural manufacturing sectors (SMNA), industrial sectors (SINA), nonindustrial sectors (SNI) are directly extracted from quarterly accounts except for the series of labour cost that has been the subject of a specific construction. The estimation sample covers the 1976-1 to 1993-4 period and corresponds to INSEE final statistics.

The labour cost series used in our study has been built for each of the three sectors with some approximations. We detail here the calculation for non agricultural manufacturing sectors: the global labour cost (for all salaried employees) is gross wage (R11_V007) to which one must add employers' contribution and substract payment subventions (R3122_SR7). Here payment subventions have been replaced by development subventions (R30_SR7). Furthermore social contributions are calculated in applying company and quasi company contribution rate to SMNA gross wage. Real labour cost is then calculated in deflating this global cost (by added value price PN1_V007/PN1_V008) and in dividing it by salaried employees of non agricultural manufacturing sectors.

The working time series used is neither the one of quarterly accounts extracted from ACEMO which doesn't take part-time job development into account, nor the synthetic indicator calculated by the French Labour Ministry, which explicitly takes part-time job development into account but was 
being re-evaluated when this study was being written. We have preferred using the series of effective working time of national accounts that we have quarterlised. It has actually very little impact on estimations, the series being very close to those of the French Labour Ministry and also close to each of the three sectors retained here. The use of the French Labour Ministry indicator or that of the annual accounts doesn't modify the sign and the coefficient value of regressions (the main differences being captured by the constant coefficient). 
Appendix 2

Univariate estimations of productivity targets

TABLE 1 - Estimation and test of the existence of a long-run relationship on the 76.1 - 96.4 period $^{6}$

\begin{tabular}{|c|c|c|}
\hline Series in logarithm & $\begin{array}{c}\text { Stationary } \\
\text { Residual } \\
\text { at } 5 \%\end{array}$ & Estimated long-run relation \\
\hline $\begin{array}{l}\text { Non agricultural } \\
\text { manufacturing } \\
\text { sectors }\end{array}$ & no $^{7}$ & $\begin{array}{l}\begin{array}{l}\mathrm{y}_{\mathrm{t}}-(\mathrm{n}+\mathrm{h})_{\mathrm{t}}= \\
\qquad .415(\mathrm{w}-\mathrm{p})_{\mathrm{t}}-3.790+0.004 \mathrm{t}+\mathrm{u}_{\mathrm{t}} \\
\text { Standard Error }=0.02178 \quad(-12.22) \quad(13.52)\end{array} \\
\begin{aligned} \mathrm{y}_{\mathrm{t}}-(\mathrm{n}+\mathrm{h})_{\mathrm{t}}= & -2.557+0.006 \mathrm{t}+\mathrm{u}_{\mathrm{t}} \\
& (-457.91)(56.75)\end{aligned} \\
\text { Standard Error }=0.02366 \mathrm{R}^{2}=0.9751 \quad \bar{R}^{2}=0.9787\end{array}$ \\
\hline Industrial sectors & no & 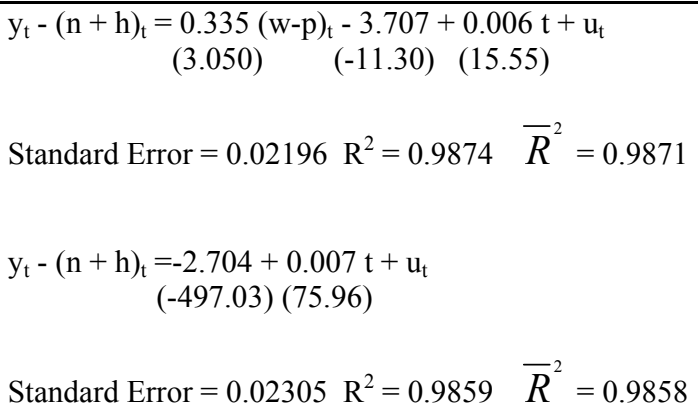 \\
\hline $\begin{array}{l}\text { Non-industrial } \\
\text { sectors }\end{array}$ & no & $\begin{array}{l}\begin{array}{l}\mathrm{y}_{\mathrm{t}}-(\mathrm{n}+\mathrm{h})_{\mathrm{t}}= \\
\qquad .355(\mathrm{w}-\mathrm{p})_{\mathrm{t}}-3.507+0.003 \mathrm{t}+\mathrm{u}_{\mathrm{t}} \\
(-10.29)(10.01)\end{array} \\
\text { Standard Error }=0.02460 \mathrm{R}^{2}=0.9587 \quad \bar{R}^{2}=0.9576 \\
\begin{array}{r}\mathrm{y}_{\mathrm{t}}-(\mathrm{n}+\mathrm{h})_{\mathrm{t}}=-2.459+0.004 \mathrm{t}+\mathrm{u}_{\mathrm{t}} \\
(-403.87)(41.18)\end{array} \\
\text { Standard Error }=0.02583 \mathrm{R}^{2}=0.9538 \quad \bar{R}^{2}=0.9533\end{array}$ \\
\hline
\end{tabular}

N.B. All series are extracted from quarterly accounts. Employment is in salaried employment (in manpower).

\footnotetext{
${ }^{6}$ When the (w-p) is not included in the equation, it actually boils down to testing the stationarity of hourly productivity around a linear trend.

7 « no » means the absence of a co-integrating relationship.

${ }^{8}$ The figure in brackets denotes T Stats.
} 
TABLE 2 - Estimation and test of the existence of a long-run relationship on the 76.1 - 96.4 period $^{9}$

\begin{tabular}{|c|c|c|}
\hline Series in logarithm & $\begin{array}{c}\text { Stationary } \\
\text { Residual } \\
\text { at } 5 \%\end{array}$ & Estimated long-run relation \\
\hline $\begin{array}{l}\text { Non agricultural } \\
\text { manufacturing } \\
\text { sectors }\end{array}$ & no $^{10}$ & $\begin{array}{l}\begin{array}{l}\mathrm{y}_{\mathrm{t}}-\mathrm{n}_{\mathrm{t}}=-0.082(\mathrm{w}-\mathrm{p})_{\mathrm{t}}+3.754+0.005 \mathrm{t}+\mathrm{u}_{\mathrm{t}} \\
\quad(-1.59)^{11} \quad(24.44) \quad(30.06)\end{array} \\
\text { Standard Error }=0.01078 \mathrm{R}^{2}=0.9921 \quad \bar{R}^{2}=0.9920 \\
\mathrm{y}_{\mathrm{t}}-\mathrm{n}_{\mathrm{t}}=3.509+0.004 \mathrm{t}+\mathrm{u}_{\mathrm{t}} \\
\quad(1365.68)(100.53) \\
\text { Standard Error }=0.01088 \mathrm{R}^{2}=0.9919 \quad \bar{R}^{2}=0.9918\end{array}$ \\
\hline Industrial sectors & no & $\begin{array}{l}\mathrm{y}_{\mathrm{t}}-\mathrm{n}_{\mathrm{t}}=-0.077(\mathrm{w}-\mathrm{p})_{\mathrm{t}}+3.587+0.007 \mathrm{t}+\mathrm{u}_{\mathrm{t}} \\
\quad(-0.81) \quad(12.61) \quad(19.57) \\
\text { Standard Error }=0.01904 \mathrm{R}^{2}=0.877 \quad \bar{R}^{2}=0.9874 \\
\quad \begin{array}{l}\mathrm{y}_{\mathrm{t}}-\mathrm{n}_{\mathrm{t}}=3.355+0.007 \mathrm{t}+\mathrm{u}_{\mathrm{t}} \\
\quad(748.20)(81.00)\end{array} \\
\text { Standard Error }=0.01900 \quad \mathrm{R}^{2}=0.9876 \quad \bar{R}^{2}=0.9875\end{array}$ \\
\hline $\begin{array}{l}\text { Non-industrial } \\
\text { sectors }\end{array}$ & no & $\begin{array}{l}\mathrm{y}_{\mathrm{t}}-\mathrm{n}_{\mathrm{t}}=-0.182(\mathrm{w}-\mathrm{p})_{\mathrm{t}}+4.149+0.004 \mathrm{t}+\mathrm{u}_{\mathrm{t}} \\
\quad(-3.24) \quad(25.02) \quad(22.95) \\
\text { Standard Error }=0.01197 \quad \mathrm{R}^{2}=0.919 \quad \bar{R}^{2}=0.9815 \\
\mathrm{y}_{\mathrm{t}}-\mathrm{n}_{\mathrm{t}}=3.610+0.003 \mathrm{t}+\mathrm{u}_{\mathrm{t}} \\
\quad(1209.50)(62.80) \\
\text { Standard Error }=0.01264 \mathrm{R}^{2}=0.9796 \quad \bar{R}^{2}=0.9793\end{array}$ \\
\hline
\end{tabular}

\footnotetext{
${ }^{9}$ When the (w-p) is not included in the equation, it actually boils down to testing the stationarity of hourly productivity around a linear trend.

${ }_{10}$ « no » means the absence of a co-integrating relationship.

${ }^{11}$ The figure in brackets denotes T Stats.
} 


\section{Appendix 3 \\ The econometric methodology}

\section{Estimation results}

The lag length choice used in the specification of the unrestricted VAR-ECM model can significantly influenced the estimation results ${ }^{12}$ and it is thus crucial to determine it both on economic and statistical considerations (see Gonzalo, 1994). Three criteria have been used here : (i) the Schwarz' Bayesian information criterion and the Hannan-Quinn criterion as well as global Fisher's tests, (ii) the absence of autocorrelation and heteroscedasticity in the residuals of the model equations, (iii) the coherence of the estimated parameters with the theoretical expectations. Finally, the adopted model consists of a lag of four quarters for non agricultural manufacturing sectors and industrial sectors and of five quarters for non industrial ones.

The next step is to test the number of cointegrating relationships existing between the four variables under consideration. In a first step, these tests have been carried out in a system with an unrestricted constant, as well as a linear drift constrained to lie in the cointegrating space ${ }^{13}$. Then, the cointegrating rank and the status of these deterministic components have been tested simultaneously ${ }^{14}$. The two LR test statistics (trace test and Lambda max test ${ }^{15}$ ) for cointegration testing and also the critical value taken from de Osterwald-Lenum (1992), are reported in table 4. These tests indicate the existence of a unique cointegrating relation between the four variables of the system in each group of sectors. This result was not straightforward since as shown by Engle and Granger (1987), there can exist up to three long run relations between four variables ${ }^{16}$.

\footnotetext{
${ }^{12}$ This choice is a crucial stage of the analysis: indeed, the simulations made by Boswijk and Franses (1992), Gonzalo (1994) show that under-fitting leads to underestimating the number of long run relations, whereas over-fitting leads to overestimating this number.

${ }^{13}$ Let us recall that if the linear deterministic trend is not constrained to lie in the co-integrating space, the presence of a non-zero deterministic trend outside the long run relations indicates the presence of a quadratic trend in every component of the system taken in level, since the system is written in first differences, which is not economically satisfactory.

${ }^{14}$ It is now well-known that the asymptotic distributions of the cointegration tests crucially depend on the deterministic components (which are not explicitly modelled) in the system. In particular, these tests are conditioned by the possible presence of a constant or a linear drift in the long run relations. It is therefore important to give a sensible status to these determinist terms, and hence the necessity to implement suitable econometric tests.

${ }^{15}$ The Lambda max test statistic is the likelihood ratio of the null hypothesis $\mathrm{H}_{2}(r):$ « there exists at most $r$ cointegration relations » against the alternative hypothesis $\mathrm{H}_{2}(r+1)$ : « there exists at most $r+1$ cointegration relations», and the Trace test statistic is the likelihood ratio of the null hypothesis $\mathrm{H}_{2}(r)$ against the alternative hypothesis $\mathrm{H}_{1}(n)$ « there exists $n$ cointegration relations », with $r=n, \ldots, 0$.

${ }^{16}$ The outcome of the cointegration analysis remains unchanged if we use the critical values recently tabulated by Pesaran, Shin and Smith (1999].
} 
Table 1 - Estimation of the number of cointegrating relationships

a) Non agricultural manufacturing sectors

\begin{tabular}{llclc}
\hline \hline Ho against $\mathrm{Ha}$ & \multicolumn{3}{c}{$\lambda_{\text {max }}$ test } & Trace test \\
& Statistic & $\begin{array}{c}\text { Critical value } \\
(\text { at } 5 \%)\end{array}$ & Statistic & $\begin{array}{c}\text { Critical value } \\
(\text { at } 5 \%)\end{array}$ \\
$\mathrm{r}=0$ against $\mathrm{r}=1$ & $49.16 * *$ & 30.5 & & 63.0 \\
$\mathrm{r} \leq 1$ against $\mathrm{r}=2$ & 20.73 & 25.5 & $29.93 * *$ & 42.4 \\
$\mathrm{r} \leq 2$ against $\mathrm{r}=3$ & 5.15 & 19.0 & 9.03 & 25.3 \\
$\mathrm{r} \leq 3$ against $\mathrm{r}=4$ & 3.88 & 12.2 & 3.88 & 12.2 \\
& & & & \\
\hline \hline
\end{tabular}

b) Industrial sectors

\begin{tabular}{llclc}
\hline \hline Ho against $\mathrm{Ha}$ & \multicolumn{2}{c}{ Trace test } \\
& Statistic & Critical value & Statistic & $\begin{array}{c}\text { Critical value } \\
(\text { at } 5 \%)\end{array}$ \\
& & $($ at $5 \%)$ & & 63.0 \\
$r=0$ against $r=1$ & $42.63 *$ & 30.5 & $68.37 *$ & 42.4 \\
$r \leq 1$ against $r=2$ & 14.85 & 25.5 & 25.74 & 25.3 \\
$r \leq 2$ against $r=3$ & 7.74 & 19.0 & 10.89 & 12.2 \\
$r \leq 3$ against $r=4$ & 3.14 & 12.2 & 3.14 & \\
\hline \hline
\end{tabular}

c) Non industrial sectors

\begin{tabular}{llllc}
\hline \hline Ho against $\mathrm{Ha}$ & \multicolumn{3}{c}{ Trace test } \\
& Statistic & Critical value & Statistic & $\begin{array}{c}\text { Critical value } \\
(\text { at } 5 \%)\end{array}$ \\
$r=0$ against $r=1$ & $30.84 *$ & 28.1 & & 53.1 \\
$r \leq 1$ against $r=2$ & 16.25 & 22 & $63.88 * *$ & 34.9 \\
$r \leq 2$ against $r=3$ & 11.74 & 15.7 & 33.03 & 20.0 \\
$r \leq 3$ against $r=4$ & 5.04 & 9.2 & 16.78 & 9.2 \\
\hline \hline
\end{tabular}

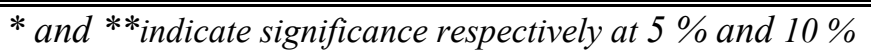

Table 5 reports the maximum likelihood estimations of the cointegrating vectors and the error correction coefficients for each group of sectors. 
Table 2 - Maximum likelihood estimations of normalised cointegrating vectors and of error-correction coefficients

\begin{tabular}{|c|c|c|c|}
\hline \multirow[t]{2}{*}{ Variables } & \multicolumn{3}{|c|}{ Normalised cointegrating vectors } \\
\hline & NAMS & $I S$ & NIS \\
\hline $\mathrm{n}$ & 1.000 & 1.000 & 1.000 \\
\hline $\mathrm{y}$ & -0.786 & -1.172 & -0.555 \\
\hline $\mathrm{h}$ & 0.083 & 0.762 & 0.254 \\
\hline$(w-p)$ & 0.083 & 0.304 & 0.212 \\
\hline constant & - & - & -4.068 \\
\hline trend & -0.003 & 0.006 & - \\
\hline \multirow[t]{2}{*}{ Variables } & Error correction coefficients & & \\
\hline & NAMS & $I S$ & NIS \\
\hline $\mathrm{n}$ & -0.014 & -0.020 & -0.011 \\
\hline $\mathrm{y}$ & 0.262 & 0.162 & 0.175 \\
\hline $\mathrm{h}$ & -0.016 & 0.018 & -0.024 \\
\hline$(w-p)$ & 0.244 & 0.069 & 0.188 \\
\hline
\end{tabular}

Thus, the long run relationship existing between the four variables writes for each group of sectors as follows :

$$
\begin{aligned}
& \mathrm{n}_{\mathrm{t}}=0.786 \mathrm{y}_{\mathrm{t}}-0.083 \mathrm{~h}_{\mathrm{t}}-0.083(\mathrm{w}-\mathrm{p})_{\mathrm{t}}-0.003 \text { trend } \\
& \mathrm{n}_{\mathrm{t}}=1.172 \mathrm{y}_{\mathrm{t}}-0.762 \mathrm{~h}_{\mathrm{t}}-0.304(\mathrm{w}-\mathrm{p})_{\mathrm{t}}-0.006 \text { trend } \\
& \mathrm{n}_{\mathrm{t}}=0.555 \mathrm{y}_{\mathrm{t}}-0.254 \mathrm{~h}_{\mathrm{t}}-0.212(\mathrm{w}-\mathrm{p})_{\mathrm{t}}+4.068
\end{aligned}
$$

\section{Tests of robustness}

Before interpretating these estimations results it is important to make the following comments on their robustness. Systematic Likelihood Ratio tests on the deterministic components have been implemented. These tests lead to accept a specification of the Vector Error Correction Model (VARECM), with an unrestricted constant in the short run, as well as a linear deterministic trend constrained to lie in cointegrating relationships for non agricultural manufacturing sectors and industrial sectors, and with a constant in the long-run for non-industrial sectors. Furthermore the adopted normalisation is sufficient in both cases to identify the parameters of the cointegrating relation. Moreover several test statistics have been calculated in order to check the quality of the multivariate estimation (Lagrange Multiplicator test for serial correlation of order 5; White heteroskedasticity test, 1980; ARCH tests, Autoregressive Conditional Heteroscedasticity; JarqueBera normality test). These tests indicate that the VAR-ECM representation is congruent with the data since the usual hypotheses concerning residuals are verified for the four equations of the three estimated VAR-ECM.

To improve these first results and the econometric estimation of the VAR-ECM, three kind of additional tests have been implemented. The results of these tests are not reported here because of limited space ${ }^{17}$, but they can easily be summarized as follows since clear patterns emerge from them.

\footnotetext{
${ }^{17}$ They are available upon request.
} 
- First, a sequence of tests was implemented in order to determine if some system variables could be excluded from the estimated long run relation established previously. These tests indicate that at a 5 $\%$ level of significance all the four variables effectively belong to the cointegrating space for each of the three sectors.

- Then, we have re-tested the stationarity of each variable around a linear trend for the non agricultural manufacturing sectors and the industrial ones ${ }^{18}$. For instance, to test if output (q) is stationary around a linear drift for non agricultural manufacturing sectors, one has to test if vector b' $=\left(\begin{array}{llll}1 & 0 & 0 & 0\end{array}\right)$ belongs or not to the cointegrating space. The results of these tests are categorical, since they reject in every case the stationarity hypothesis around a linear drift of the four variables. It is also interesting to test if per capita and hourly productivity are stationarity around a linear drift for each of the two sectors. The tests indicate that this hypothesis is largely rejected by data whatever the retained level of significance is. Thus, the results of the stationarity tests applied in the multivariate framework, where the interdependences between variables are explicitly modelled, are concomitant with those applied previously in the univariate framework. These tests indicate that the variables are characterised by a stochastic non stationarity (namely integrated of order 1), rather than a deterministic non stationarity (namely stationary around a linear drift).

- Finally, in a third time, having examined the structure of the co-integrating space, it is important to test if the cointegrating relation put in evidence for each of the three sectors explicitly belongs to all the equations of the model VAR-ECM. It is a weak exogeneity test of the different variables of the VAR-ECM ${ }^{19}$. These tests check if the structural hypothesis imposed a-priori by applied researchers in univariate employment equations, i.e. the exogeneity of the variables appearing in the right members is verified empirically ${ }^{20}$. These tests show that for each of the three sectors the variables (output, labour cost and working time) are weakly exogenous at a $5 \%$ level of significance. Hence on the 76.1-96.4 period we can pursue a valid inference without any loss of information from this employment equation alone without explicitly modelling the three equations describing the evolution of output, working time and labour cost.

Structural hypotheses have also been tested, as the equality of manpower coefficients to 1 and the joint hypothesis of manpower and working time coefficients to 1 , but they have all been rejected whatever the considered sector is. Finally the system has been re-estimated by recursive least squares until 1996-4. This estimation method is commonly used in empirical studies since it enables to follow the evolution of the estimated vector of coefficients when we add a new piece of information at each step in this estimation. Moreover it also offers the possibility to build graphs and to carry out tests in order to appreciate the parameter stability through time and to perform Chow tests so as to detect a possible break. The graphs reported in appendix 4 have been built in reestimating successively the model, but each time for a longer period (the first estimation has been done for the $76.1-83.2$ period). The graph examination doesn't reveal any particular break in the three sectors, so that the parameters of these three multivariate models seem to be steady through time as it is confirmed by the global stability graphs.

Thus, the misspecification and constancy tests indicate the three estimated VAR-ECM model to be a satisfactory representation of the data.

\footnotetext{
${ }^{18}$ The results of these tests don't have much interest for the industrial sectors because in these sectors the cointegration relation does not include a linear trend, but only a constant..

${ }^{19}$ See Rault (2000) and Pradel and Rault (2003) for a discussion on weak-exogeneity and non-causality.

${ }^{20}$ This assumption has actually no specific reason to hold empirically.
} 
Appendix 4

Chow tests to evaluate coefficient stability in the multivariate estimation

- Non agricultural manufacturing sectors
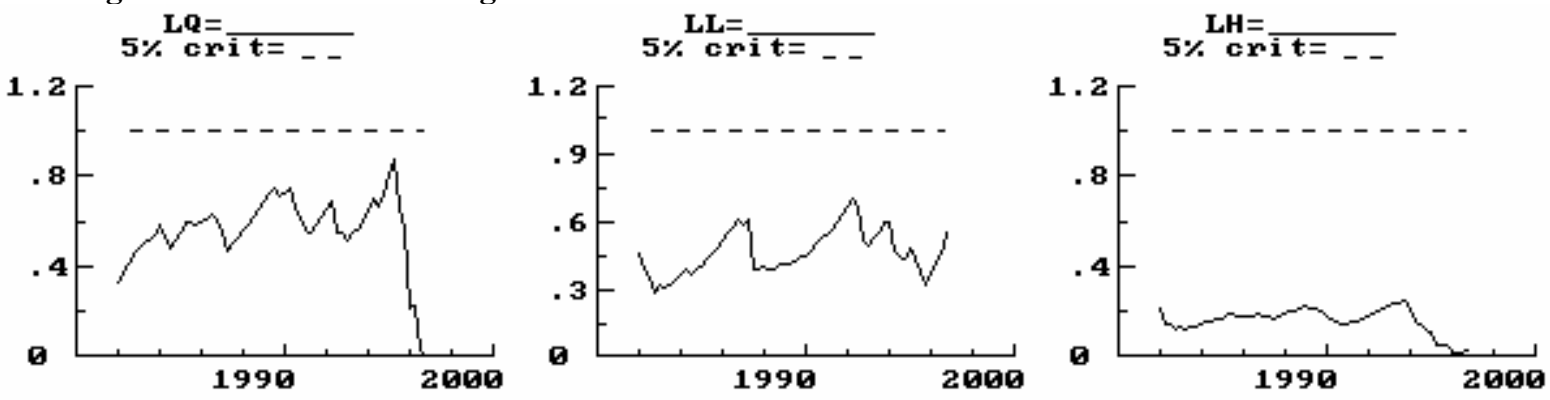

5\% $\stackrel{\text { Crit }}{\mathbf{W}} \mathbf{P}=$

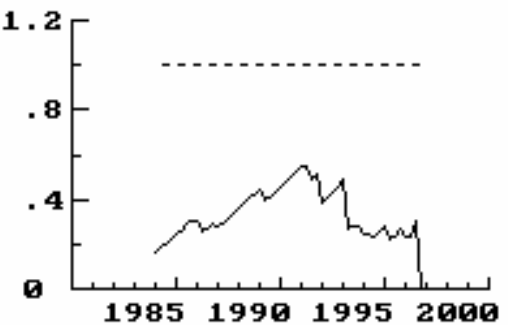

Global Stability

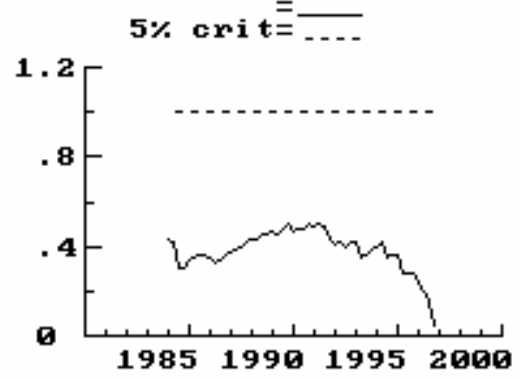

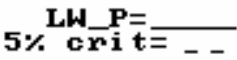
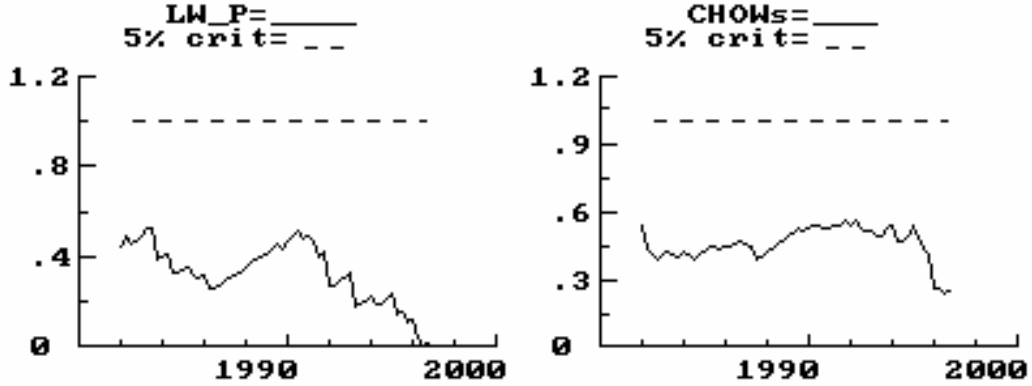

- Industrial sectors

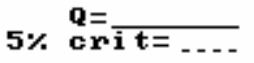

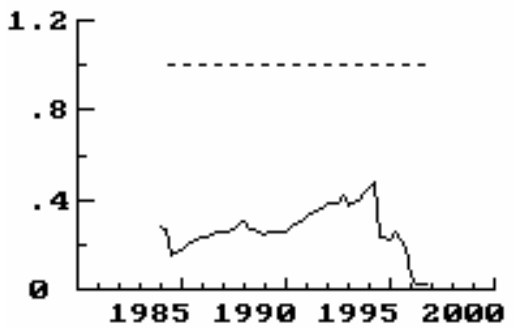

$\mathbf{L}=$

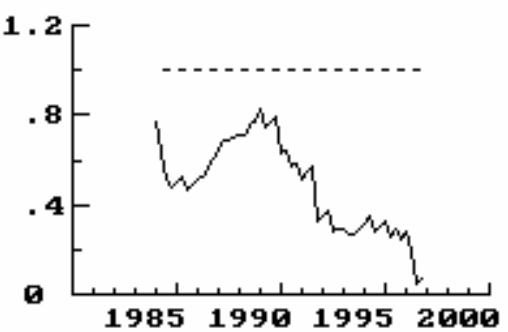

5\% $\underset{\operatorname{crit}=\ldots}{\mathrm{H}=\ldots}$

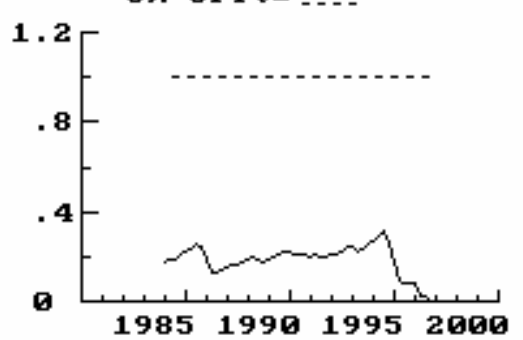

Global Stability 

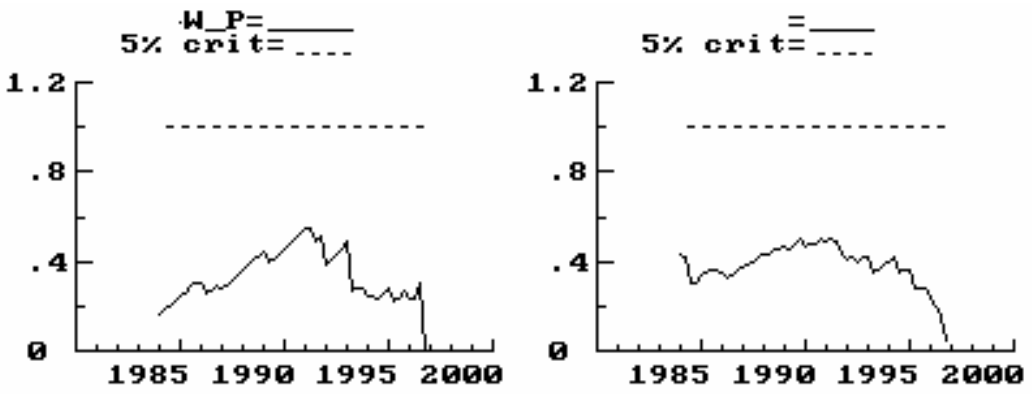

- Non industrial sectors

5\%L $=$

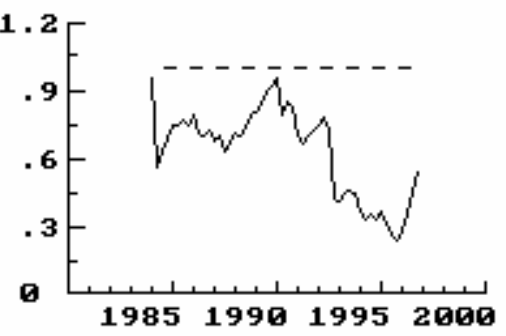

LW $P$

5\% $\operatorname{crit}=\ldots$

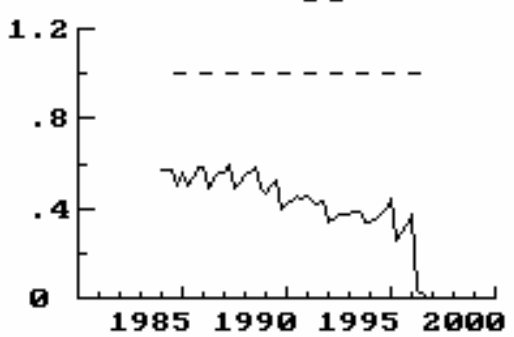

$\mathbf{L Q}=$

$5 \%$ crit $=\ldots$

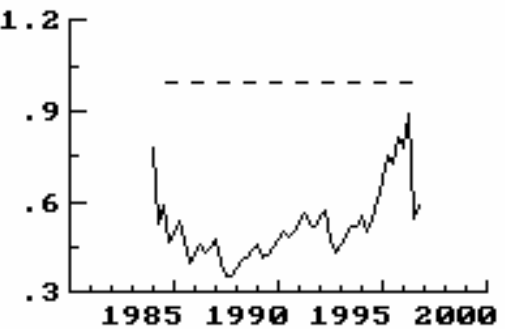

Global Stability

CHOWs

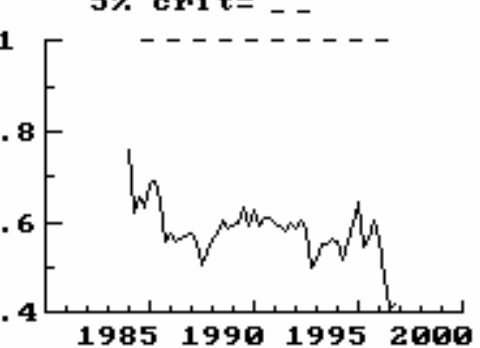




\section{IZA Discussion Papers}

\begin{tabular}{|c|c|c|c|c|}
\hline No. & Author(s) & Title & Area & Date \\
\hline 857 & $\begin{array}{l}\text { M. Francesconi } \\
\text { A. Muthoo }\end{array}$ & An Economic Model of Child Custody & 3 & $08 / 03$ \\
\hline 858 & C. U. Chiswick & $\begin{array}{l}\text { History of Historical Statistics of the United } \\
\text { States }\end{array}$ & 7 & $08 / 03$ \\
\hline 859 & R. Fahr & $\begin{array}{l}\text { Loafing or Learning? The Demand for Informal } \\
\text { Education }\end{array}$ & 5 & $08 / 03$ \\
\hline 860 & $\begin{array}{l}\text { J. Bonke } \\
\text { N. Datta Gupta } \\
\text { N. Smith }\end{array}$ & $\begin{array}{l}\text { Timing and Flexibility of Housework and Men } \\
\text { and Women's Wages }\end{array}$ & 5 & $08 / 03$ \\
\hline 861 & $\begin{array}{l}\text { Y. L'Horty } \\
\text { C. Rault }\end{array}$ & $\begin{array}{l}\text { Inflation, Minimum Wage and Other Wages: An } \\
\text { Econometric Study on French Macroeconomic } \\
\text { Data }\end{array}$ & 1 & $08 / 03$ \\
\hline 862 & $\begin{array}{l}\text { J. T. Addison } \\
\text { C. R. Belfield }\end{array}$ & Union Voice & 3 & $08 / 03$ \\
\hline 863 & C. U. Chiswick & $\begin{array}{l}\text { Immigrant Religious Adjustment: An Economic } \\
\text { Approach to Jewish Migrations }\end{array}$ & 1 & $08 / 03$ \\
\hline 864 & $\begin{array}{l}\text { D. Cobb-Clark } \\
\text { C. Ryan } \\
\text { R. Breunig }\end{array}$ & $\begin{array}{l}\text { A Couples-Based Approach to the Problem of } \\
\text { Workless Families }\end{array}$ & 6 & $08 / 03$ \\
\hline 865 & S. W. Polachek & $\begin{array}{l}\text { Mincer's Overtaking Point and the Lifecycle } \\
\text { Earnings Distribution }\end{array}$ & 5 & $08 / 03$ \\
\hline 866 & A. Constant & $\begin{array}{l}\text { Immigrant Adjustment in France and Impacts on } \\
\text { the Natives }\end{array}$ & 1 & $08 / 03$ \\
\hline 867 & $\begin{array}{l}\text { T. J. Dohmen } \\
\text { B. Kriechel } \\
\text { G. A. Pfann }\end{array}$ & $\begin{array}{l}\text { Monkey Bars and Ladders: The Importance of } \\
\text { Lateral and Vertical Job Mobility in Internal } \\
\text { Labor Market Careers }\end{array}$ & 1 & $08 / 03$ \\
\hline 868 & $\begin{array}{l}\text { P. Brañas Garza } \\
\text { S. Neuman }\end{array}$ & $\begin{array}{l}\text { Analyzing Religiosity Within an Economic } \\
\text { Framework: The Case of Spanish Catholics }\end{array}$ & 5 & $08 / 03$ \\
\hline 869 & $\begin{array}{l}\text { A. B. Krueger } \\
\text { A. Mas }\end{array}$ & $\begin{array}{l}\text { Strikes, Scabs and Tread Separations: Labor } \\
\text { Strife and the Production of Defective } \\
\text { Bridgestone/Firestone Tires }\end{array}$ & 3 & $09 / 03$ \\
\hline 870 & $\begin{array}{l}\text { S. Klasen } \\
\text { A. Launov }\end{array}$ & $\begin{array}{l}\text { Analysis of the Determinants of Fertility Decline } \\
\text { in the Czech Republic }\end{array}$ & 4 & $09 / 03$ \\
\hline 871 & $\begin{array}{l}\text { Y. L'Horty } \\
\text { C. Rault }\end{array}$ & $\begin{array}{l}\text { The Impact of Growth, Labour Cost and Working } \\
\text { Time on Employment: Lessons from the French } \\
\text { Experience }\end{array}$ & 5 & 09/03 \\
\hline
\end{tabular}

An updated list of IZA Discussion Papers is available on the center's homepage www.iza.org. 